\title{
РОССИЙСКАЯ СМЕРТНОСТЬ В СВЕТЕ ПОТРЕБЛЕНИЯ АЛКОГОЛЯ
}

\author{
АЛЕКСАНДР НЕМЦОВ
}

\begin{abstract}
В новейшей истории России было три существенных случая снижения потребления алкоголя, сопровождавшихся снижением смертности. Первое (в связи с антиалкогольной кампанией 1985 г.) продолжалось 3 года, второе - 4 года (1995-1998 г2.). В 2004 г. началось третье снижение потребления, которое часто связывается с антиалкогольными законами 2005 г. Предпосылки этого снижение были заложены в 2000 г. Ее обозначили создание Росспиртпрома (РСП) и антипивная кампания, а с 2009 г. дело РСП продолжило Росалкогольрегулирование (РАР). Главным в деятельности РСП и РАР было банкротство нескольких сотен предприятий алкогольной промышленности. Это и многое другое в деятельности РСП и РАР принесло нестабильность, а иногда и дезорганизацию алкогольного рынка, что сопровождалось ограничением доступности спиртных напитков и могло стать существенной причиной снижения их потребления и смертности в 2004 г. По сути, в 2000 г. началась вторая антиалкогольная кампания. Объектом первой был потребитель, второй - алкогольный рынок. Целью первой кампании было снижение потребления алкоголя и оздоровление экономики. Целью второй было наполнение бюджета с помощьюю подавления нелегального рынка и перевода потребителей в лоно легального. Методы первой кампании снижение производства и ограничение торговли, методы второй менялись по ходу кампании. Главным оставалось вытеснение с рынка мелких и средних предпринимателей. Предполагалось, что они являются основными поставщиками нелегальной продукции. К методам второй кампании следует отнести введение Единой государственной автоматизированной системь (ЕГАИС), рост акциизов и минимальной цень на спиртное, а также жесткую, иногда криминальную конкуренцию. Инструментом первой кампании стало административное давление. Главными инструментами второй стали последовательно РСП и РАР.

В результате не произошло ни оздоровления экономики в первую кампанию, ни наполнения бюджета за счет алкоголя во вторую. Снижение потребления и смертности в первую кампанию было непродолжительным, вторая в этом отношении была более эффективной в связи с нарастающим дефицитом бюджета из-за экономического кризиса. И та, и другая кампания вызвали рост потребления нелегального алкоголя.
\end{abstract}

Ключевые слова: потребление алкоголя, смертность в России, антиалкогольная компания, нелегальный алкоголь.

\section{ВВЕДЕНИЕ}

В России потребление алкоголя играет значительную роль в жизни отдельных людей и всего общества. Эта роль многогранна, многогранны также интересы, связанные с производством и потреблением алкоголя, частные интересы здесь нередко переплетаются с государственными. Вокруг спиртного создается сложный конгломерат взаимосвязей, часто трудных для анализа, для выявления причинно-следственных отношений, в том числе и в проблеме влияния алкоголя на смертность.

АЛЕКСАНДР ВИКЕНТЬЕВИЧ НЕМЦОВ. МОСКОВСКИЙ НАУЧНО-ИССЛЕДОВАТЕЛЬСКИЙ ИНСТИТУТ ПСИХИАТРИИ (РосСИЯ). E-MAIL: nemtsov33@gmail.com 
Сложность взаимосвязей порождает мифы вокруг алкоголя или прямолинейные толкования эффектов потребления спиртных напитков. Один из таких мифов - высокая токсичность самогона и другого неучтенного алкоголя. Сейчас неоднократно показано, что токсичность самогона мало отличается от токсичности легально произведенных спиртных напитков [Нужный, Рожанец, Савчук 2011]. Кроме того, в последние два десятилетия произошло изменение в составе нелегального (неучтенного) потребления. В отличие от самогона, который доминировал до середины 1990-х годов и роль которого в последнее время снова усиливается, основу неучтенного потребления составляют дешевые, скрытые от обложения акцизами крепкие напитки удовлетворительного качества, которые производят легальные предприятия [Немцов 2009].

Существенно то, что бедные в России больше остальных потребляют дешевый алкоголь из нелегальных источников (рисунок 1). Соответственно, пока в России существует значительная прослойка бедных, будут существовать и спрос на нелегальный алкоголь, и высокий уровень его потребления. Главная же алкогольная проблема нашей страны как в недалеком прошлом, так и в настоящем, не столько в качестве спиртных напитков, сколько в их непомерном количестве. Это количество определяет четкость зависимости ожидаемой продолжительности жизни от размеров потребления алкоголя (рисунок 2). Если не впадать в статистический ригоризм, то можно утверждать, что рост потребления на 1 литр на человека в год (л/чел/год) в диапазоне 10-18 л «отнимает» у мужчин 1 год, у женщин 4,6 месяца жизни. Линейность соотношений ожидаемой продолжительности жизни или смертности с уровнем потребления алкоголя позволяет рассчитать связанные с алкоголем потери населения страны. Для периода 1980-2001 гг., в среднем, это 426 тыс. человек в год: 272,1 тыс. мужчин и 153,9 тыс. женщин [Немцов, Терехин 2007].

Следует подчеркнуть, что потребление алкоголя выполняет многие социальные функции [Немцов 2009], но главная - персональная. Это временный и, конечно, мнимый уход от повседневного неблагополучия как материального, так и психологического. Благоприятное действие алкоголя эфемерно противостоит житейским трудностям самого разного содержания и масштаба. Трудно представить, что было бы с нашей страной в условиях ее «сухого» существования.

В этом контексте пьянство может быть индикатором общего неблагополучия. Отсюда - наивысшее потребление у людей с наименьшими доходами, как на Западе, так и в нашей стране (рисунок 1).

После этих вводных замечаний можно соотнести потребление алкоголя со смертностью на протяжении последних 60 лет. 


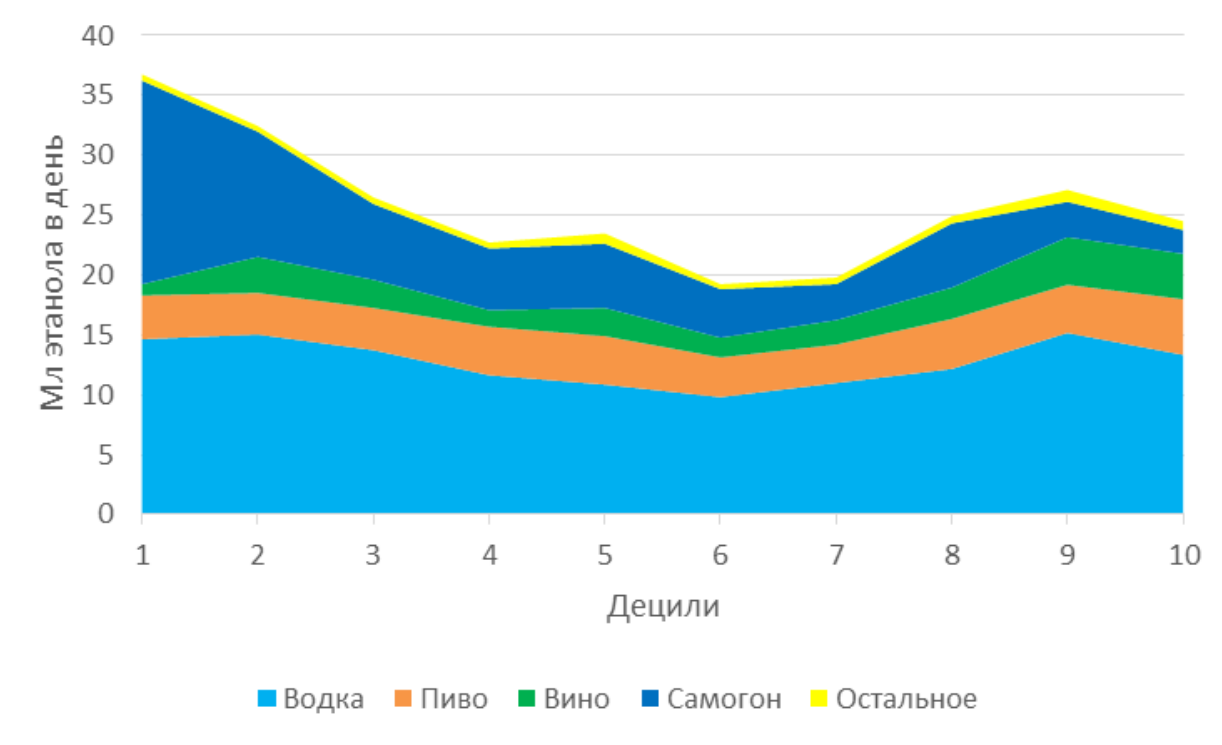

Рисунок 1. Структура потребляемых напитков в зависимости от доходов (RLMS, 11 раунд). Абсцисса - ранжирование потребителей по доходам: 1 - наименьшие, 10 наибольшие доходы

Источник: [Andrienko, Nemtsov 2006].

\section{ПОТРЕБЛЕНИЕ АЛКОГОЛЯ И СМЕРТНОСТЬ В РОССИИ В 1956-2003 ГГ.}

По сравнению с нынешним уровень потребления алкоголя в РСФСР ко времени окончания Великой Отечественной войны был сравнительно небольшим, но выше довоенного: «наркомовские сто грамм» на фронте и премиальные в тылу [Такала 2002] «раскачали» потребление вместе с активизацией самогоноварения. Кроме того, алкоголь оставался существенной статьей доходов бюджета, его официальное производство с 1960 по 1984 г. удвоилось. И соответственно начался стремительный рост потребления и смертности/снижения ожидаемой продолжительности жизни (рисунок 3). Неоднократные попытки советского руководства переломить ситуацию (1948, 1958, 1960, 1961, 1967, 1972 и 1974 г.) не дали существенного результата главным образом потому, что алкогольная политика была крайне непоследовательной.

Достойно удивления, что в большой и сильно пьющей стране никто не знает точно истинные масштабы потребления алкоголя, а государственные органы даже не пытаются их выяснить, чтобы строить алкогольную политику на научной основе. Более того, можно сказать, что в России нет алкогольной политики как последовательной цепи действенных мероприятий, ведущих к четко определенной цели. Был единственный короткий эпизод, когда в 1980 г. Госкомстат СССР получил от Правительства задание разработать методику и оценить размеры потребления самогона в стране и республиках. 


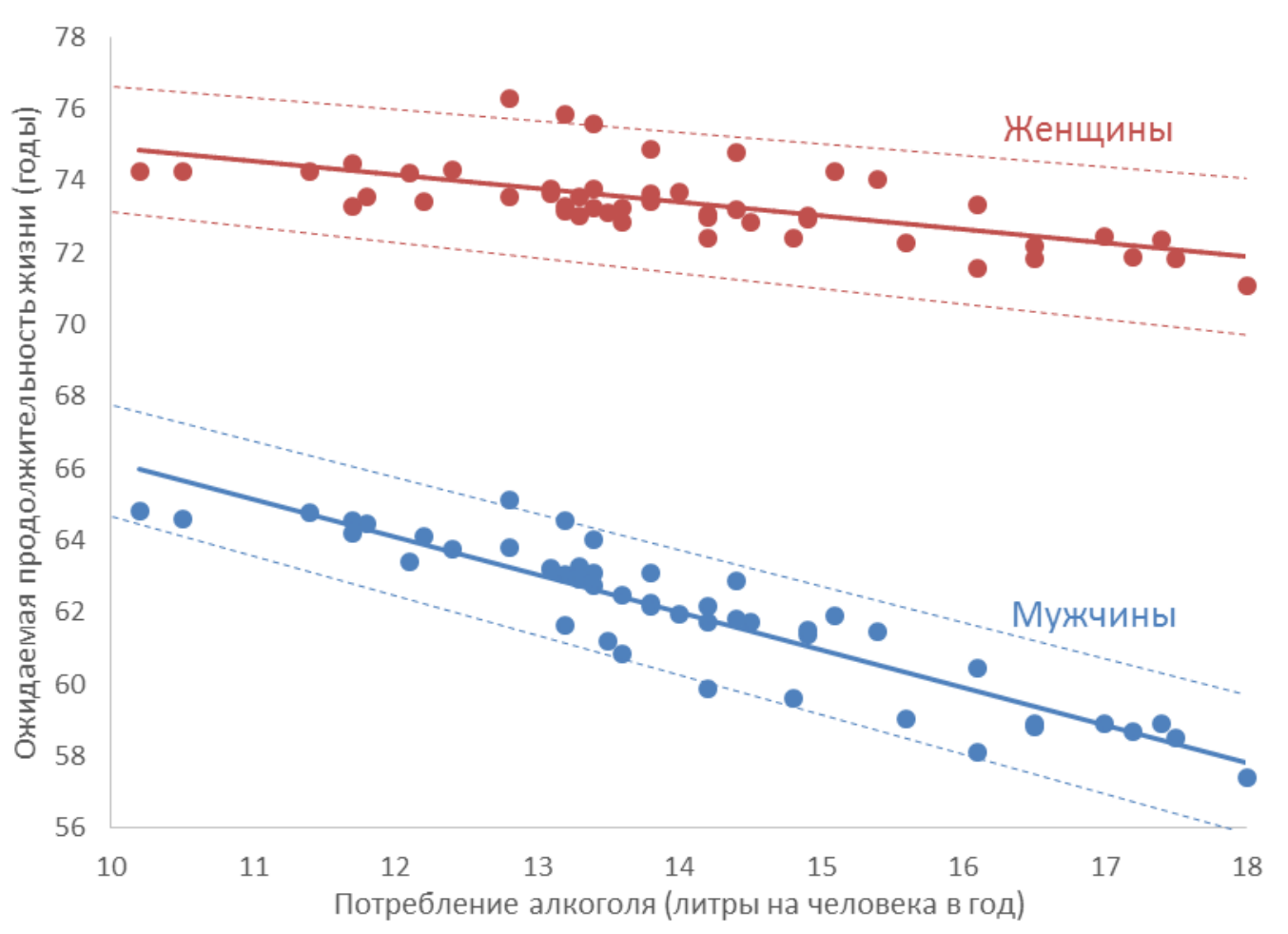

\section{Рисунок 2. Зависимость между ожидаемой продолжительностью жизни и потреблением алкоголя}

\footnotetext{
Примечание: Сплошная прямая - линия регрессии, пунктир - гранищь 95\%-ного доверительного интервала прогноза.
}

Источник: [Немиов, Шельгин 2014].

Такая методика была разработана, и на ее основе Госкомстат в 1980-1987 гг. оценивал размеры нелегальной продукции, исходя из учета сверхнормативных закупок сахара. Это была первая в советской России динамическая оценка реального потребления алкоголя (самогон + алкоголь госпродажи), хотя и засекреченная. В США (Университет Дюка) с 1960 г. расчетами потребления в СССР и РСФСР занимался экономист Владимир Тремл [Treml 1982], книга которого хранилась в спецхране. В 1981 г. к этим исследованиям присоединился автор настоящей статьи [Nemtsov 1998; 2002], ничего не ведая о предшественниках.

«Перестройка» раскрыла некоторые засекреченные материалы, в частности данные о потреблении алкоголя. В 1988-1989 гг. выяснилось, что три оценки, сделанные независимо и на совершенно разных основаниях, очень близки: накануне антиалкогольной кампании (1984 г.) общее потребление в РСФСР составляло 14,5 л/чел/год. Более поздняя оценка для 1984 г. - 14,2 л/чел/год [Немцов, Шелыгин 2014]1․

\footnotetext{
${ }^{1}$ Новая оценка потребления алкоголя была рассчитана на основе анализа смертей от отравления алкоголем с 1956 по 2013 г. К расчетным показателям был добавлен алкоголь пива, которое не приводит к смертельным отравлениям и поэтому не отражается в расчетах. Рост его продажи с 1998 по 2007 г. был в переводе на чистый алкоголь почти пятикратным.
} 
В 1985 г. началась очень жесткая антиалкогольная политическая кампания, которая положила начало значительным колебаниям потребления алкоголя и противофазным колебаниям ожидаемой продолжительности жизни (рисунок 3). Тем самым начался новый этап алкогольной и демографической истории страны.

Мировая история знает существенные падения и подъемы потребления алкоголя, например в США [Room 1991] и Великобритании [Spring, Buss 1977]. Но эти и многие другие колебания потребления продолжались десятилетиями (long waves of alcohol consumption [Holder, Edwards 1995]). В отличие от этого в России после 1984 г. сложился новый характер потребления, который можно обозначить как циклический (рисунок 3), состоящий из двух с половиной колебаний (снижение + рост): 1) 1985-1994 гг.; 2) 1995-2003 гг.; 3) 2004-2013 гг.

Причина первого резкого снижения потребления - антиалкогольная кампания 1985 г. Предпосылки и мотивы кампании в целом ясны [Немцов 2009]. Если же говорить о ее результатах, то важно подчеркнуть, что эта кампания не привела к существенному снижению потребления ни по размерам (до 10,2 л/чел/год в 1987 г.), ни по продолжительности (1985-1987, рисунок 4). Население ответило на нее невиданным до того единодушным сопротивлением - мощным производством самогона, несмотря на жестокие судебные и административные преследования. Уже в 1987 г. начался возвратный рост смертности (рисунок 3), а в 1988 г. - рост потребления алкоголя за счет самогоноварения и расширения государственной продажи в связи с существенным дефицитом бюджета. В 1992 г. был достигнут исходный (1984 г.) уровень потребления, а с началом рыночных реформ и в связи с невнятной алкогольной политикой нового руководства страны рост потребления алкоголя и смертности приобрел галопирующий темп (рисунок 3). В 1994 г. Россия поставила свой исторический, а в XX веке - мировой рекорд по потреблению алкоголя - 18 л/чел/год [Немцов, Шелыгин 2014]. Оно было выше только в конце XIX века в Германии, точнее в Пруссии (22 л/чел/год), и во Франции в первой половине и середине XX века (19,8 л/чел/год) [Simpura 1995]. Вместе с рекордом по потреблению алкоголя в 1994 г. был поставлен также рекорд по смертности в послевоенную пору.

В 1995 г. началось второе стремительное снижение потребления алкоголя и смертности вплоть до 1998 г., когда к началу дефолта потребление снизилось до 13,5 л/чел/год, т.е. на 4,5 л/чел/год за 3 года - точно так же, как во время антиалкогольной кампании. Скорее всего, решающую роль сыграли два обстоятельства. Первое - вымирание большой когорты основных потребителей алкоголя в 1991-1994(1995) гг. в результате свободного доступа к алкогольным напиткам: известно, что тяжелые пьяницы и алкоголики поглощают около половины алкоголя из общего потребления [Holder, Edwards 1995]. Возможно, в смертности 1995-1998 гг. сошлись две когорты тяжелых потребителей алкоголя: та, которая благодаря кампании пережила ее, не умерев, но реализовала риск алкогольной смертности, начиная с 1991(1992) г. в результате свободного доступа к алкоголю; вторая когорта - новые тяжелые потребители, которые сформировались во время антиалкогольной кампании в связи с относительно высоким уровнем потребления (10,213,4 л/чел/год). 


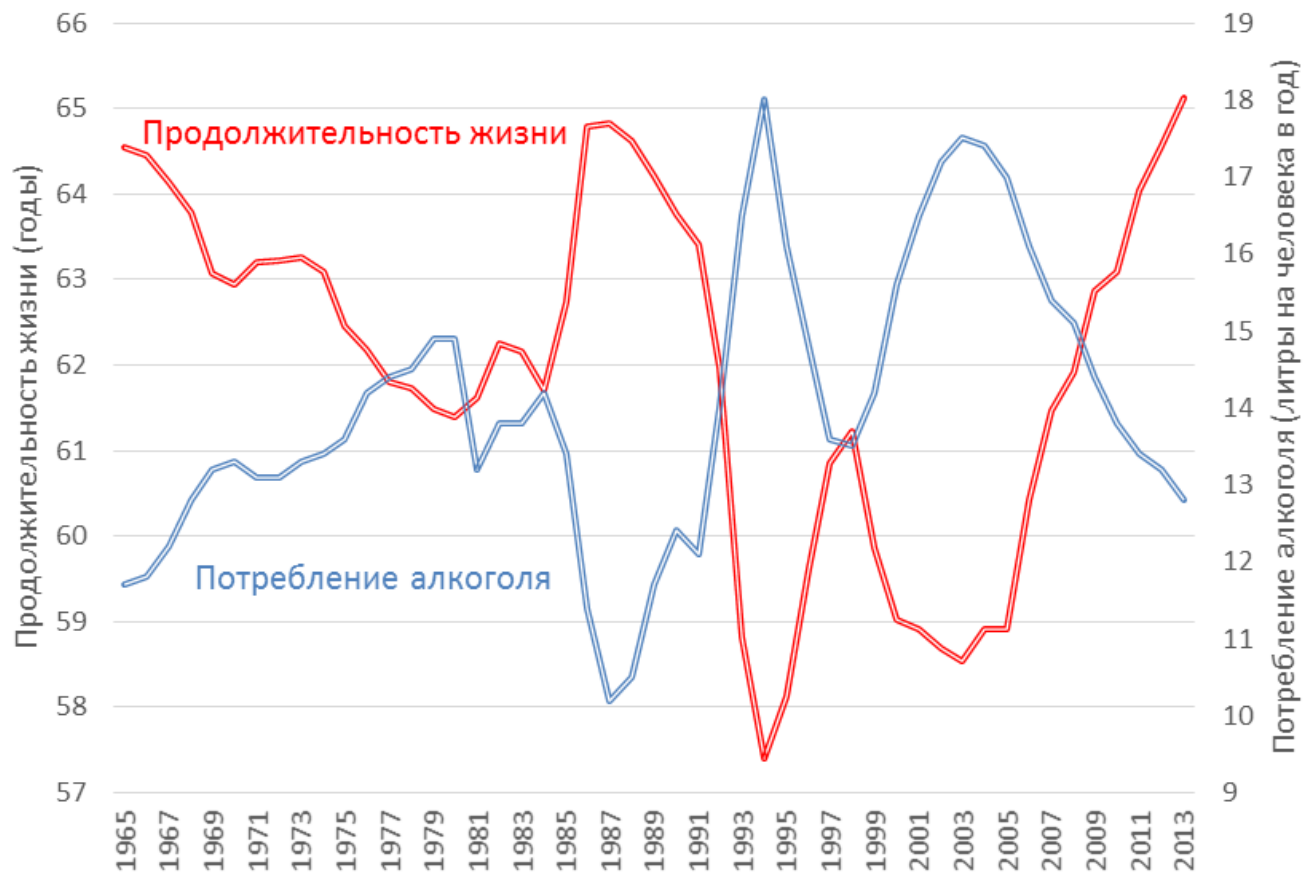

Рисунок 3. Соотношение потребления алкоголя и ожидаемой продолжительности жизни в России в 1965-2013 гг.

Источники: Данные Росстата, [Немиов, Шельгин 2014].

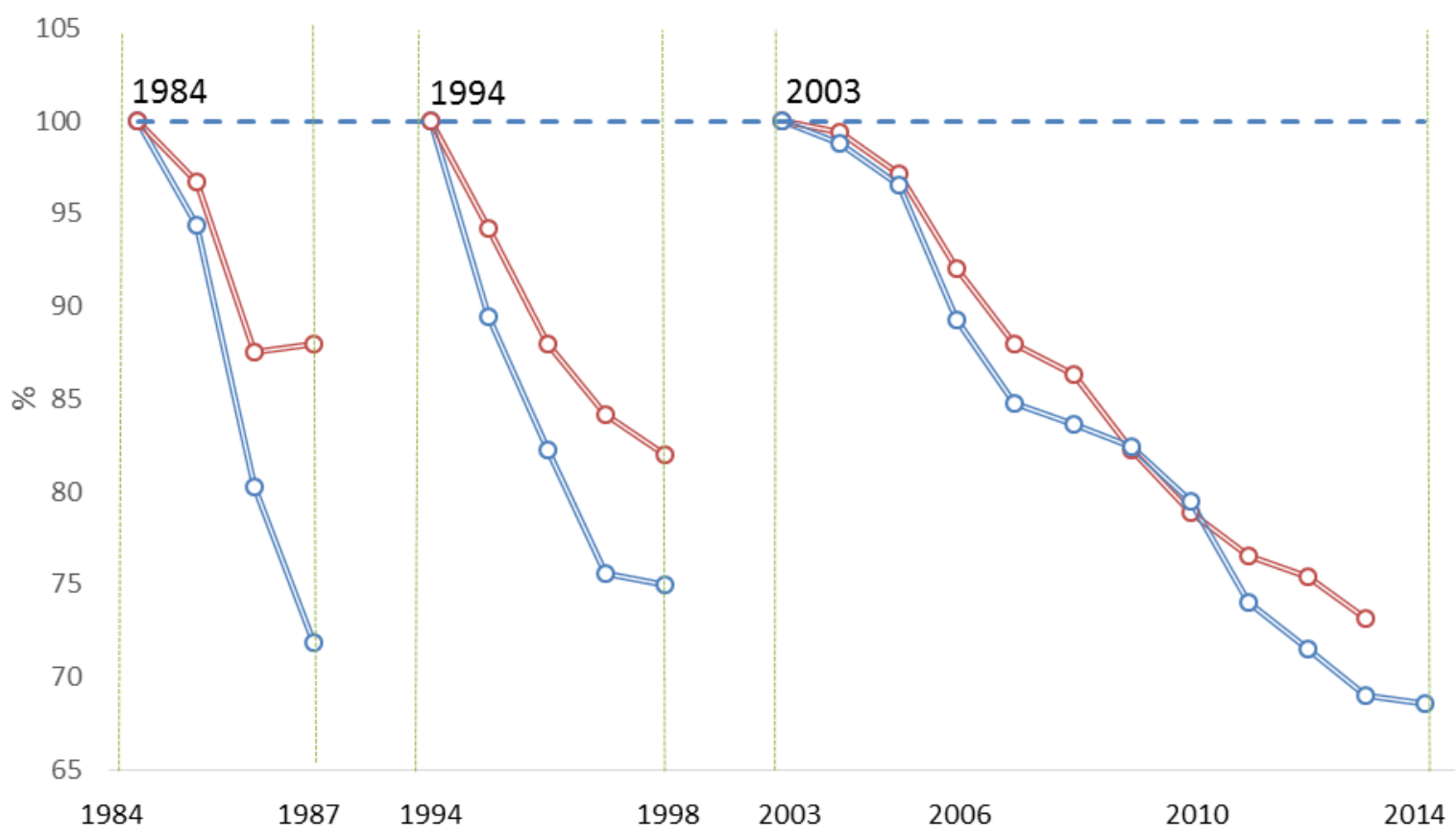

Рисунок 4. Изменения стандартизованного коэффициент смертности мужчин (красные линии) и потребления алкоголя (синие линии) в 1984-1987, 1994-1998 и в 2003-2013 гг. Показатели 1984, 1994 и 2003 гг. приняты за 100\%

Источники: Данные Росстата, [Немичов, Шельгин 2014].

Другое обстоятельство, обусловившее снижения потребления алкоголя и смертности, - резкое обнищание населения в результате рыночных реформ, вызвавших 
инфляцию и десятикратный рост цен. К этому прибавились невыплаты зарплат, ставшие массовым явлением. Доходы населения практически сравнялись с расходами, в связи с чем резко снизилась покупательная способность [Немцов 2009]. Можно думать, что это сказалось и на потреблении алкоголя. В связи с финансовыми трудностями и недобором бюджета были также предприняты значительные усилия государства в борьбе с нелегальным алкоголем, особенно ярко проявившиеся на границе с Северной Осетией. Все это и некоторые другие обстоятельства [Немцов 2009] могут объяснить снижение потребления в 1995-1998 гг. Последний год в этом ряду ознаменовался дефолтом, который за счет падения курса рубля и равновесия платежного баланса, оздоровления экономики, роста производства и ВВП вызвал повышение доходов населения и соответственно его покупательной способности. Всего за год после кризиса был восстановлен докризисный уровень жизни и потребления алкоголя. Быстрый рост потребления продолжался до 2003 г. [Немцов, Шелыгин 2014] (рисунок 3). К сожалению, возможности, открытые дефолтом и девальвацией, исчерпались к 2003 г., когда власти начали «разбираться» с бизнесом, а цены на нефть выросли и начали пополнять бюджет. Однако бюджетные проблемы были очень далеки от разрешения.

\section{ПОТРЕБЛЕНИЕ АЛКОГОЛЯ И СМЕРТНОСТЬ ПОСЛЕ 2003 Г.}

В 2004 г. началось третье по счету снижение алкогольного потребления и смертности (рисунок 4). Однако история этого снижения началась в 2000 г. вместе с приходом нового президента и началом новой алкогольной политики.

Следует сказать, что в результате ошибочной алкогольной политики в 90-е годы алкогольным рынком стали заправлять криминальные структуры, легальная доля этого рынка уменьшилась с 80\% в 1992 г. до 15\% в 1997 г., доля алкогольных акцизов в ВВП, и без того невысокая, снизилась с 0,72 до 0,30\% [Космарская 1998]. Естественно, требовалось переломить эту ситуацию.

Начало новой алкогольной политики обозначило создание Росспиртпрома (РСП) в марте 2000 г., а в декабре того же года - начало антипивной кампании по инициативе Главного санитарного врача России Г. Онищенко. Главным в деятельности РСП было банкротство нескольких сотен предприятий спиртовой и водочной промышленности, а также продажа этих предприятий по заниженной цене владельцам мощных олигополий. Предполагалось, что мелкие предприятия являются источником производства и распространения нелегального алкоголя, а их ликвидация или концентрация в руках немногих монополистов парализует поступление нелегальной продукции на рынок, и вместе с этим произойдет рост продаж легальной продукции и пополнение бюджета. РСП просуществовал до 2009 г., принес государству огромные убытки, алкогольному рынку крайнюю нестабильность в связи с перераспределением активов и неоправданной жесткостью мер РСП в отношении легальной отрасли.

Банкротство множества предприятий, их ликвидация или переход к другим владельцам нарушают производство и потоки продукции, тем самым дезорганизуют алкогольный рынок и приводят к снижению доступности спиртного и его потребления со 
всеми вытекающими из этого последствиями. $\mathrm{B}$ результате деятельность РСП парадоксальным образом могла стать причиной начала снижения потребления алкоголя в 2004 г., а следом за этим - и снижения смертности, в первую очередь, непосредственно связанной с алкоголем (рисунок 5). Эти последствия особенно отчетливо проявились в 2006-2007 гг. (см. ниже).

Такая административная активность предшествовала (!) законодательным инициативам руководства страны в виде двух законов 2005 г. Первым, помимо прочего, запрещалось с 1 января 2006 г. использовать прежние акцизные марки, которые требовалось заменить новыми. Однако новые марки были отпечатаны только в конце января - начале февраля 2006 г. и только на полулитровые бутылки водки. Марки на остальные напитки и емкости допечатывались в течение 2006 г. Это стало первым фактором дополнительной дезорганизации алкогольного рынка и, как следствие, снижения потребления алкоголя (рисунок 4) и смертности (рисунок 5).

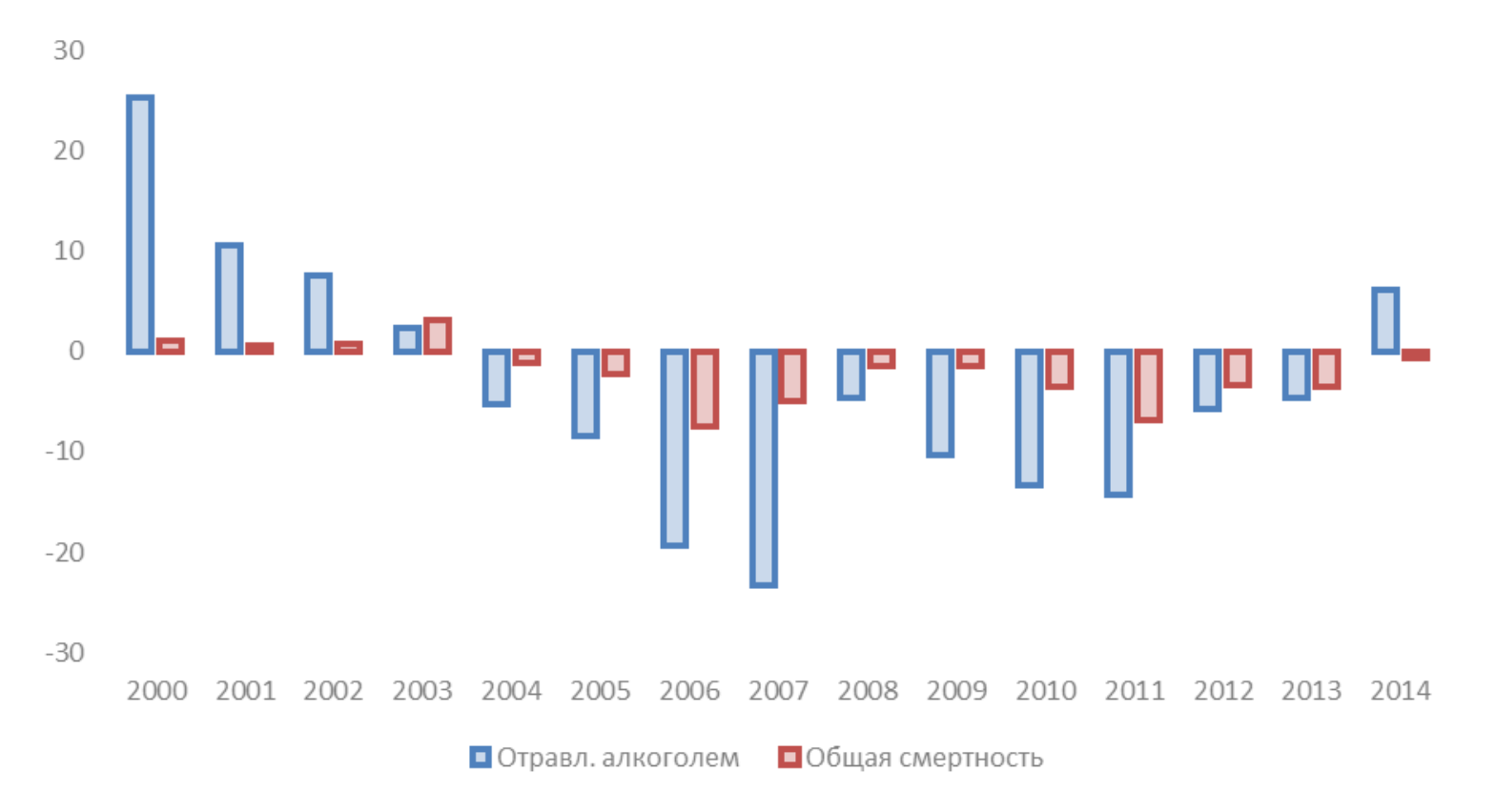

Рисунок 5. Прирост к предыдущему году общей смертности мужчин (красные столбики) и смертности мужчин от отравления алкоголем (синие столбики) в 20002014 гг., число смертей на 100000 населения

Источник: Расчет автора на основе данных Росстата.

Второй закон с 1 июля 2006 г. резко повышал уставной капитал производителей и продавцов алкогольной продукции. Эта мера была предпринята для того, чтобы удалить с рынка мелких и средних участников. Благовидным предлогом для этого были трудности их контроля в борьбе с нелегальным алкоголем. Истинная причина, скорее, в дальнейшей расчистке рынка для крупных и крупнейших производителей, которая началась еще в 2000 г. и привела к дезорганизации рынка в результате непоследовательных, а порой и криминальных действий РСП (рейдерские акции, например, в отношении московского завода «Кристалл» [Боярина 2010]). В 2006 г. к этому прибавился хаос в связи с тем, что с 1 января 2006 г. стартовала Единая государственная автоматизированная информационная система (ЕГАИС), которая предназначалась для государственного контроля над объёмом 
производства и оборота этилового спирта, а также алкогольной и спиртосодержащей продукции. Однако в условиях полной неготовности как бизнеса, так и государства ЕГАИС не начала работать. К 2008 г. ситуация на алкогольном рынке нормализовалась, снижение потребления и смертности резко замедлилось (рисунок 5), оно вернулось к прежним темпам, наметившимся в 2004-2005 гг. [Немцов, Шелыгин 2015]. Но, самое главное, законы 2005 г. не выполнили своего назначения: продажи легального крепкого алкоголя продолжали снижаться (рисунок 6), снижались и бюджетные поступления.

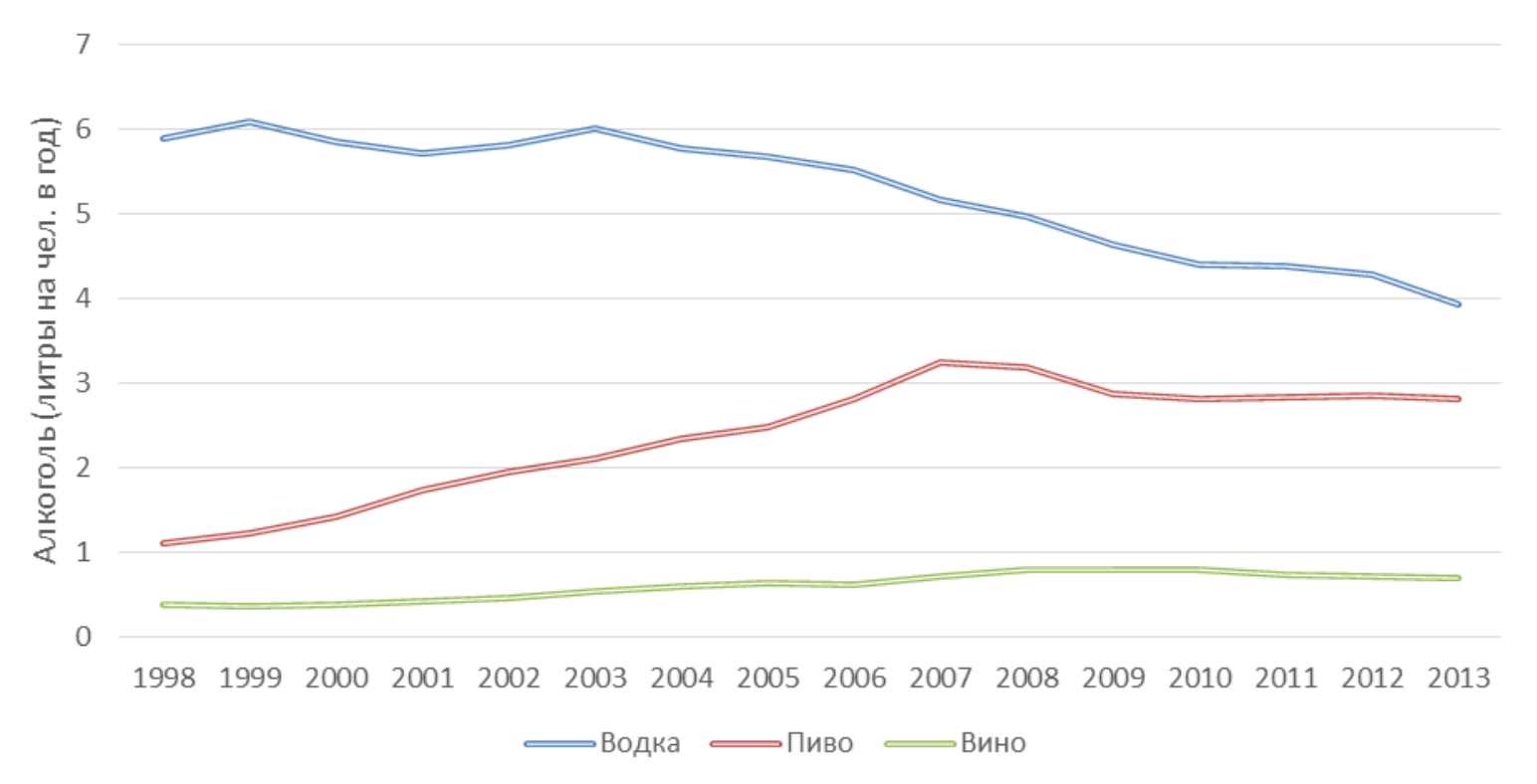

\section{Рисунок 6. Зарегистрированная продажа водки, пива и вина в пересчете на чистый алкоголь}

Источник: Расчет автора на основе данных и показателей Росстата.

Вторым законом была введена важная для нашей темы мера: с 1 июля 2006 г. вводились новые денатурирующие добавки, более токсичные и менее чувствительные органолептически. Результатом этого стала «эпидемия» острых гепатитов с последующей смертностью от заболеваний печени, из-за чего на 6-7 лет задержалось снижение этого показателя (рисунок 7 [Немцов, Шелыгин 2015]) при снижении потребления, начавшемся в 2004 г.

После 2008 г. снижение потребления алкоголя и, как следствие, смертности, результат все нарастающего давления на алкогольный рынок (таблица в Приложении). Одним из таких механизмов была ЕГАИС. Начиная с 2006 г. было несколько попыток внедрения ЕГАИС, и каждая начиналась с нового проекта, нового исполнителя, новых бюджетных ассигнований. Так, стоимость очередной разработки ЕГАИС (2011 г.), по разным подсчетам, составила около 600 млн руб. [АЛКОГОЛЬ.РУ]. Важно, что каждая попытка внедрения сопровождалась дестабилизацией рынка. Последняя и окончательная дата полного внедрения ЕГАИС - 1 января 2016 г. Иначе говоря, история внедрения ЕГАИС продолжается уже 10 лет. Пока безрезультатно. Между тем некоторые западные исследователи неоднократно писали, что снижение потребления алкоголя, рост ожидаемой продолжительности жизни и снижение смертности отчасти обусловлены пресловутой ЕГАИС - единственной в мире технической системой регулирования рынка. 


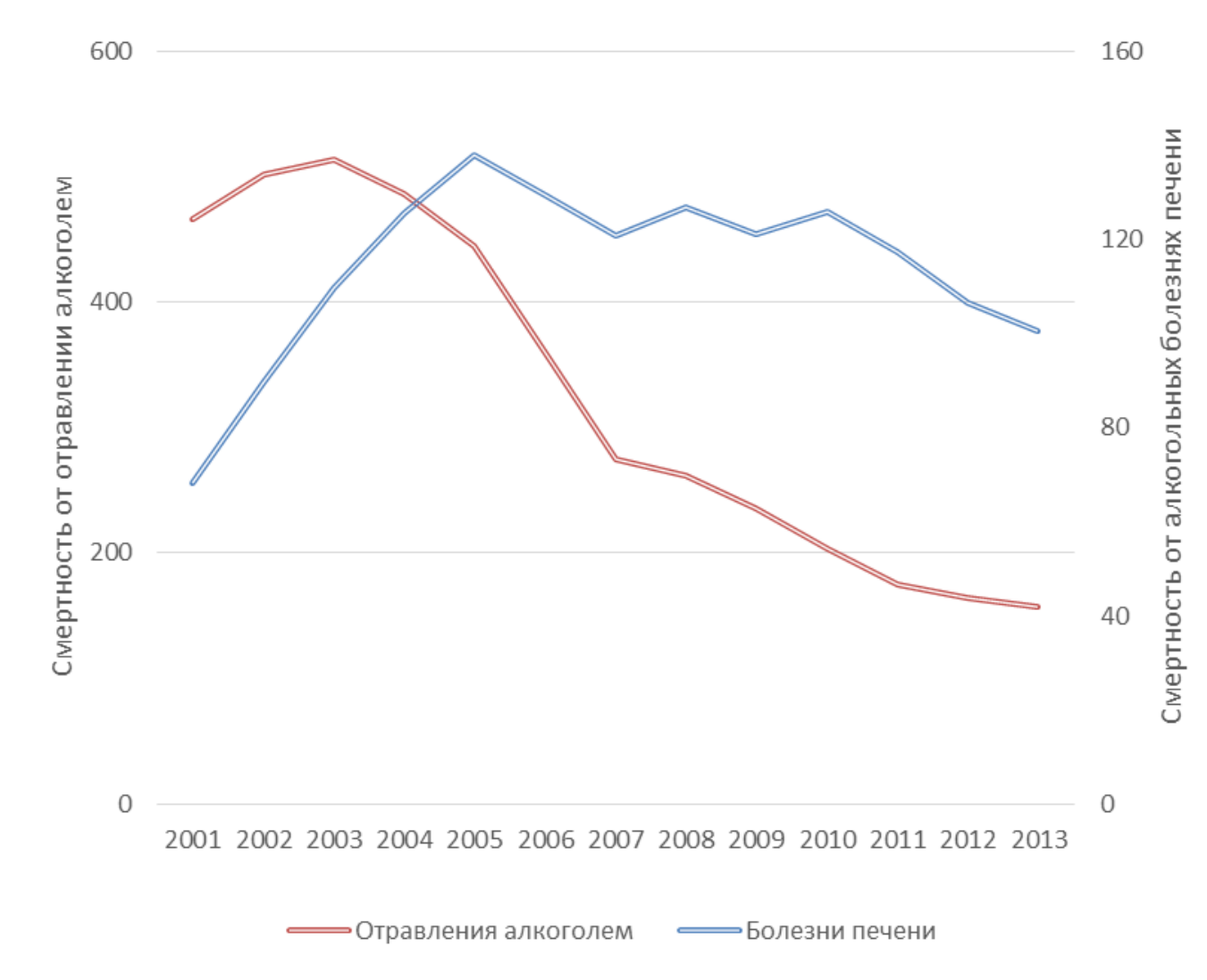

\section{Рисунок 7. Смертность от отравления алкоголем и от болезней печени в 2001-2013 гг., на 1000000}

Источник: [Немиов, Шелыгин 2015].

В отличие от ЕГАИС более действенным был значительный рост акцизов и повышение минимальной цены на полулитровую бутылку водки (рисунок 8). Но эта мера привела к дальнейшему снижению госпродажи и резкому снижению поступлений в бюджет. Все эти меры затрудняли доступность легальных спиртных напитков и переводили потребителей на нелегальный алкоголь. Например, коэффициент собираемости акциза на крепкий алкоголь в 2007-2011 гг. составлял 46,3-55,9\%, тогда как на пиво - 88,2-94,9\% [Соколов 2013]. 25 июня 2015 г. председатель Совета Федерации В.И. Матвиенко заявила на заседании палаты, что «около 290 миллиардов рублей ежегодно недополучает бюджет из-за производства нелегальной продукции» и назвала «бюджетные потери катастрофическими». 26 ноября В.И. Матвиенко вернулась к этой теме и добавила, что «доля легально произведенной алкогольной продукции в текущем году снизилась до рекордных $35 \%$ при сохранении общего объема потребления».

Нелегальный рынок алкоголя за последние 6 лет увеличился с 40 до 64\%, из них 30\% реализуется в легальной лицензионной розничной сети, а оставшиеся $34 \%$ - в нелегальных торговых точках. Основные нелегальные производства сосредоточены в КабардиноБалкарии, Северной Осетии, Дагестане и Подмосковье [АЛКОГОЛЬ.РУ]. Большая часть нелегальных производств и торговых точек - это обанкротившиеся предприятия, лишенные лицензий, но именно поэтому неподконтрольные Росалкогольрегулированию (РАР). 


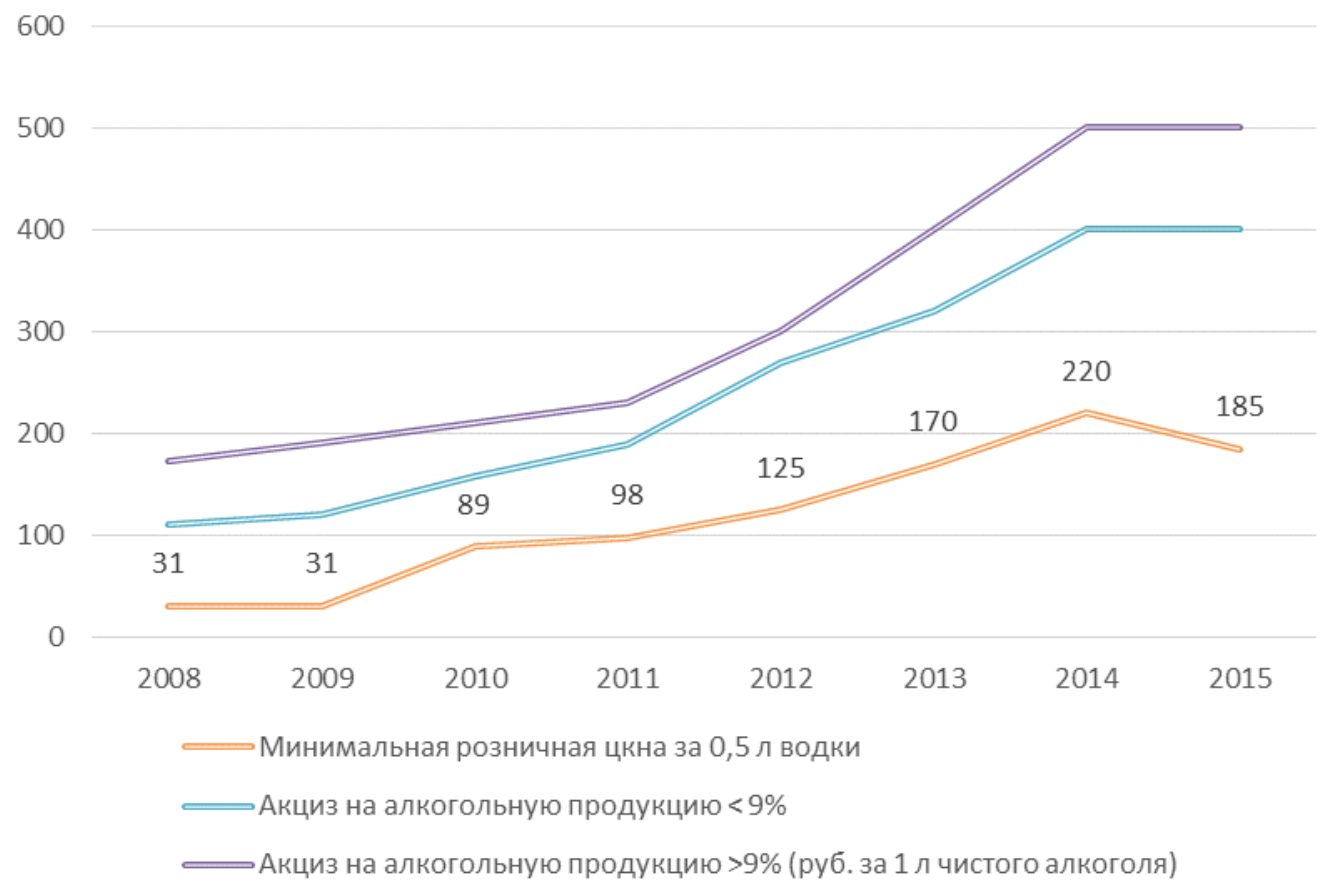

Рисунок 8. Акцизы на 1 л спирта и минимальная цена за 0,5 л водки, руб.

Источник: Данные Росстата.

Разные источники свидетельствуют о нарастании нелегального производства и оценивают его в 60-64\%. А это значит, что происходит перемещение все нарастающей части потребителей с официального рынка на нелегальный. Но такая передислокация покупателей-потребителей требует некоторого времени в связи с организацией нового производства и новых потоков продукции. В результате восстановление привычных норм потребления алкоголя происходит с лагом, что, вероятно, способствовало снижению потребления, которое продолжалось 10 лет вплоть до 2013 г. В 2012-2013 гг. уменьшение потребления алкоголя и связанных с ним показателей смертности затормозилось (рисунок 5). А в 2014 г. обнаружился рост смертности мужчин от отравления алкоголем на 6,2\% по сравнению с 2013 г. (рисунок 5). Этот вид смертности, как показала антиалкогольная кампания 1985 г., наиболее динамично откликается на изменение потребления алкоголя [Shkolnikov, Nemtsov 1997; Nemtsov 1998; 2002; Shkolnikovetal. 2004]. Можно предположить, пока только предположить, что в 2014 г. произошло завершение снижения потребления алкоголя и начался возвратный рост. С 2003 по 2013 г. снижение потребления алкоголя составило 4,7 л/чел/год [Немцов, Шелыгин 2014]. Это близко к темпам снижения во время антиалкогольной кампании - 4,0 л/чел/год с 1984 по 1987 г., правда, за более короткий срок (3 года против 10 лет). Иначе говоря, снижение в последние годы происходило непрерывно, но в 3 раза медленнее: 0,47 л/чел/год против 1,60 в 1985-1987 гг. Так, очень приблизительно, можно оценить различие эффективности антиалкогольных мер во время двух периодов снижения потребления алкоголя. Снижение стандартизованного коэффициента смертности в 2003-2013 гг. составило 31,0\% у мужчин и 29,4\% у женщин против 12,1 и 7,0\% в 1984-1987 гг.

Важная и обнадеживающая тенденция последних 10-15 лет: изменение состава алкогольных напитков в официальной продаже (рисунок 6). Связано это с тем, что в 
середине 1990-х в России начали функционировать крупные международные пивные компании, появилось мощное производство сравнительно неплохого пива. С 1998 г. начался рост его потребления - население спонтанно стало выбирать из двух зол (водка или пиво) меньшее: пиво как более слабый напиток приносит меньше вреда здоровью. К 2007 г. потребление пива увеличилось почти в 5 раз (81,3 л/чел/год), хотя это еще далеко до европейских лидеров (Чешская Республика - 156,9, Германия - 115,8 л/чел/год [WHO 2014]).

Рост потребления пива происходил во всем мире. К тому времени, когда в 1982 г. ВО3 призвала правительства переориентировать население своих стран на слабые алкогольные напитки, вино и пиво, в развитых странах уже происходил процесс смены структуры потребления. Смещение потребления алкоголя на пиво происходило также в «винных» странах. В послевоенную пору это было вызвано изменением стереотипа жизни, нарастанием мобильности, ростом ценности здоровья. Всему этому мешали крепкие напитки. Увеличение потребления слабых напитков с акцентом на пиво в России происходит потому, что у нас никогда не было винных традиций. Сейчас предпринимаются вполне здравые попытки развивать и стимулировать виноделие, но из-за нашего климата производство вина всегда будет ограничено, а поэтому оно останется дорогим и малодоступным. Если не считать попыток внедрить в потребление энергетики, против которых начинается активная борьба, из слабых алкогольных напитков остается пиво.

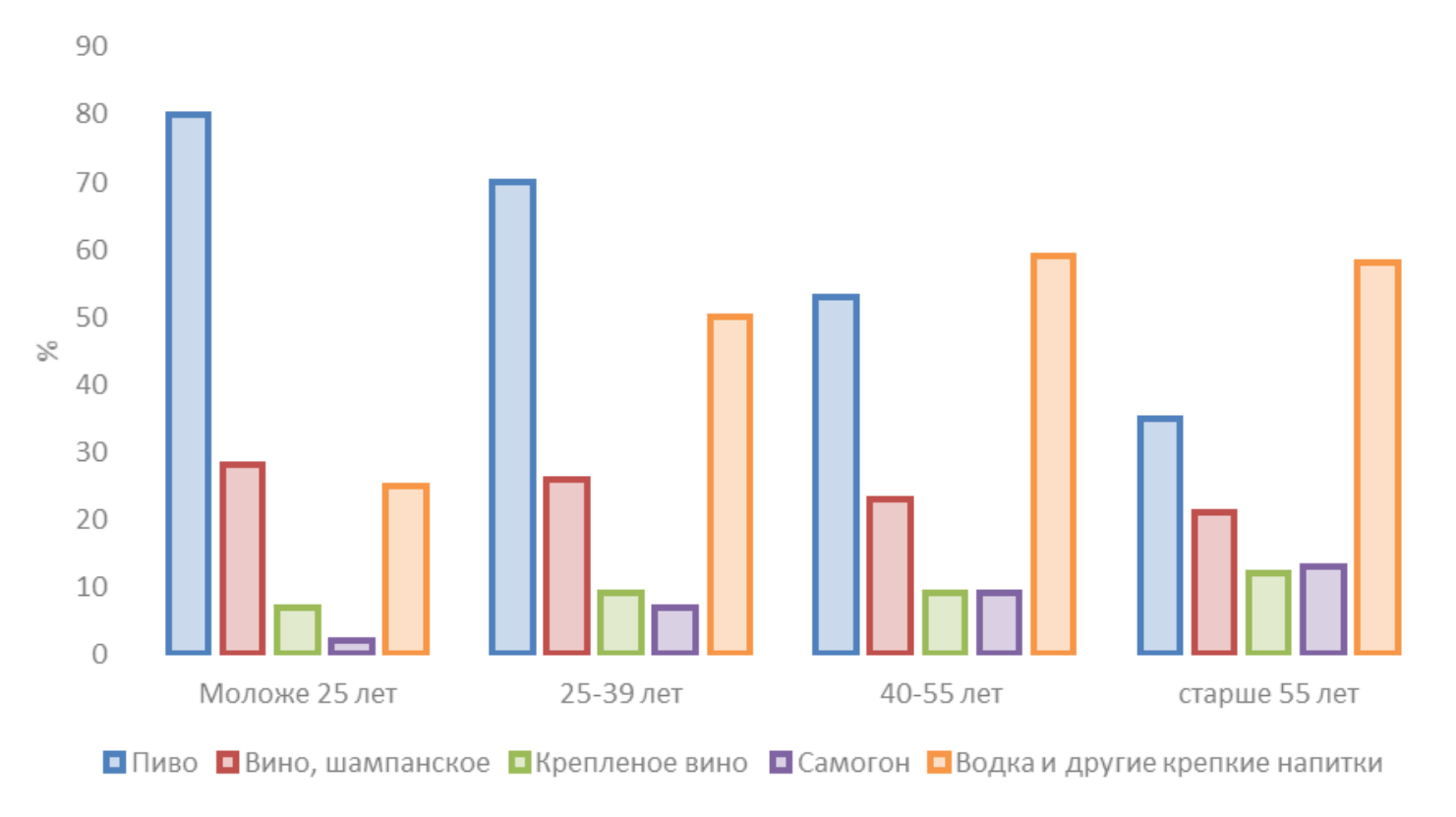

\section{Рисунок 9. Структура потребления спиртных напитков в зависимости от возраста потребителей}

Источник: [Denisova, Kartseva 2012].

Структура потребления алкоголя особенно резко изменилась у людей моложе 40 лет [Denisova, Kartseva 2012], у которых в потреблении начало доминировать пиво (рисунок 9), тогда как в старших возрастах продолжает доминировать водка. При этом было показано, как, по мере омоложения потребителей, доля пива нарастает, а доля водки падает [Kueng, Yakovlev 2014]. В исторической перспективе, которую можно выразить сентенцией «пили, 
пьют и будут пить», это явление следует считать благом уже потому, что ни одно острое отравление пивом со смертельным исходом не зафиксировано. Параллельно с ростом потребления пива снижаются официальные продажи водки (рисунок 6), и эти два процесса могут быть одной из причин снижения общего потребления алкоголя в 2004-2013 гг. На рисунке 6 видно, что с 2008 г. рост потребления пива был приостановлен в результате законодательных акций и ряда административных мер, часть которых можно отнести за счет деятельности, главным образом, водочного лобби, но также производителей стекла, ратовавших за отмену пластиковых бутылок (ПЭТ) в качестве тары для пива и замены их стеклянной тарой. Жесткая конкурентная активность водочного бизнеса против пивного может задержать переход потребителей с водки на пиво и тем самым сказаться на демографических процессах.

\section{ПРИЧИНЫ СНИЖЕНИЯ СМЕРТНОСТИ ПОСЛЕ 2003 Г.}

Для начала важное замечание: с точки зрения демографических показателей, главная беда, связанная со злоупотреблением алкоголем, это не алкоголизм, как часто говорится и пишется, а бытовое пьянство. Алкоголизм или патологическая зависимость - медицинское явление. На уровне диспансерного учета оно составляет 1,4\% населения страны [Основные показатели... 2012], а общее количество больных предположительно не превышает 4-5\% населения [Немцов 2009]. Истинных размеров пьянства никто не знает, к тому же провести границу между бытовым потреблением алкоголя и пьянством или же квалифицировать пьянство непросто из-за градуального нарастания потребления алкоголя. Неизвестно также распределение алкогольных проблем в когорте потребителей. Однако немногие исследования свидетельствуют, что пьянство охватывает около $40 \%$ мужчин трудоспособного возраста и 15\% женщин [Бехтель 1986]. Именно эта часть населения вносит основной вклад в алкогольный урон страны: риск наступления смерти у мужчин, которые выпивают 3 или более полулитровых бутылки водки в неделю, до достижения 55 лет составляет 35\% [Zaridze 2014]. Организация экономического сотрудничества и развития (OECD) оценивает связанную с алкоголем смертность в России в 30,5\% и считает нашу страну лидером в мире по этому показателю [OECD 2015]. Оценки автора для 1980-2007 гг. - 24\% мужских и 15\% женских смертей [Немцов, Терехин 2007; Немцов 2009]. Разводовский оценивает потери выше - 41 и 28\% соответственно [Razvodovsky 2012], а Леон и соавторы связывают с опасным потреблением алкоголя 51\% смертей мужчин 25-54 лет против 13\% в контрольной группе [Leon et al. 2007].

При сопоставлении показателей разных авторов надо иметь в виду, что алкогольные показатели, привязанные к определенным периодам времени, отражают состояние проблем именно в эти периоды, так как алкогольная ситуация в России очень динамична. Это выразилось в большой скорости и размахе изменения смертности: у мужчин - 43,3\% от среднего значения на протяжении 30 лет (у женщин - 37,2\%). Колебания смертности составили 2,5 цикла, практически синхронных с циклами потребления (см. выше; рисунок 3). Третий цикл можно считать незавершенным, так как в течение 10 лет (2004-2013 гг.) снижение смертности, как и рост ожидаемой продолжительности жизни, происходили с переменной скоростью. Однако 2014 г. дал некоторые основания думать о начале 
завершения и третьего цикла, хотя один год не указ - подождем следующего, а лучше еще одного, чтобы твердо судить о том, что происходит.

Главная особенность третьего снижения смертности - это его продолжительность: 10-11 лет против 3-4 лет при двух предыдущих. Этот период представляет особый интерес именно из-за причин его продолжительности.

Крупное социальное явление в большой стране трудно связать с одной причиной. Скорее их было несколько. При этом нельзя не вспомнить, что была государственная программа развития здоровья до 2020 г., предполагавшая ассигнование на это 2,04 млрд руб.

Григорьев и Андреев [Grigoriev, Andreev 2015] считают, что вклад мер политики в снижение смертности в России после 2003 г. был небольшим, и связывают это снижение с колебаниями смертности в предшествующие годы. Они делают исключение только для 2006-2007 гг. также, как это делают другие авторы [Neufeld, Rehm 2013], которые, однако, отметили важный факт: новая алкогольная политика стала проводиться с 2000 г. Pridemore и соавторы [Pridemoreetal. 2014] связывают действие законов 2005 г. со снижением смертности вплоть до 2010 г. (конец периода исследования). Еще дальше пошли Халтурина и Коротаев [Khalturina, Korotaev 2015]. Эти авторы довели свой анализ до 2013 г. и сочли, что эффект законов 2005 г., введенных в 2006 г., продолжался во все последующие годы.

Анализ причин смерти и ожидаемой продолжительности жизни между 2003 и 2012 г. привел Школьникова и соавторов [Школьников и др. 2014] к выводу, что наибольший вклад в рост продолжительности жизни внесло снижение смертности взрослых от болезней системы кровообращения и внешних причин, наиболее тесно связанных с потреблением алкоголя. Тут следует вспомнить, что снижение смертности от болезней системы кровообращения, особенно ишемической болезни сердца, наблюдалось также во время антиалкогольной кампании 1985 г. [Shkolnikovetal. 2004]. Тогда снизились и другие основные виды смертности (рисунок 10, [Nemtsov 1999]). Существенно, что в тот период почти единственной причиной снижения смертности было сокращение потребления алкоголя; многие декларативные заявления о вкладе в этот процесс духовного подъема и надежд, вызванных перестройкой, нельзя считать доказанными. Снижение потребления алкоголя в 2000-х годах, которое произошло, как считает Радаев, еще до первого политического вмешательства в 2006-2007 гг., он более реалистично связывает с ростом ВВП и реального дохода населения, а перерыв снижения в 2011-2013 гг. - с кризисом 20082009 гг. [Radaev 2015]. При этом он совершенно справедливо считает, что трудно определить точную роль политических интервенций. Это следует отнести и к последующим выкладкам этой статьи.

Объяснение, предложенное Григорьевым и Андреевым [Grigoriev, Andreev 2015], кажется заманчивым, особенно при взгляде на рисунок 3. Можно думать, что продолжается инерция колебательного процесса, заведенного антиалкогольной кампанией 1985 г. Но при этом объяснение авторов хорошо бы дополнить раскрытием механизма, который поддерживает колебательный процесс после 2003 г. Гипотетически таким механизмом могла бы быть разная скорость как вымирания основных потребителей алкоголя (пьяниц и алкоголиков), так и восстановления этой когорты. Иначе говоря, можно допустить, что при 
росте потребления вымирание происходит быстрее в сравнении с увеличением когорты новых пьяниц и алкоголиков. К сожалению, проверка этой гипотезы крайне затруднительна из-за разрушения в 1990-е годы наркологической службы в той ее части, которая обеспечивала ежемесячный учет состоящих на учете больных алкоголизмом и пьяниц из группы риска. Кроме того, предположению о колебательном процессе мешает затянувшееся на 10 лет снижение смертности после 2003 г.

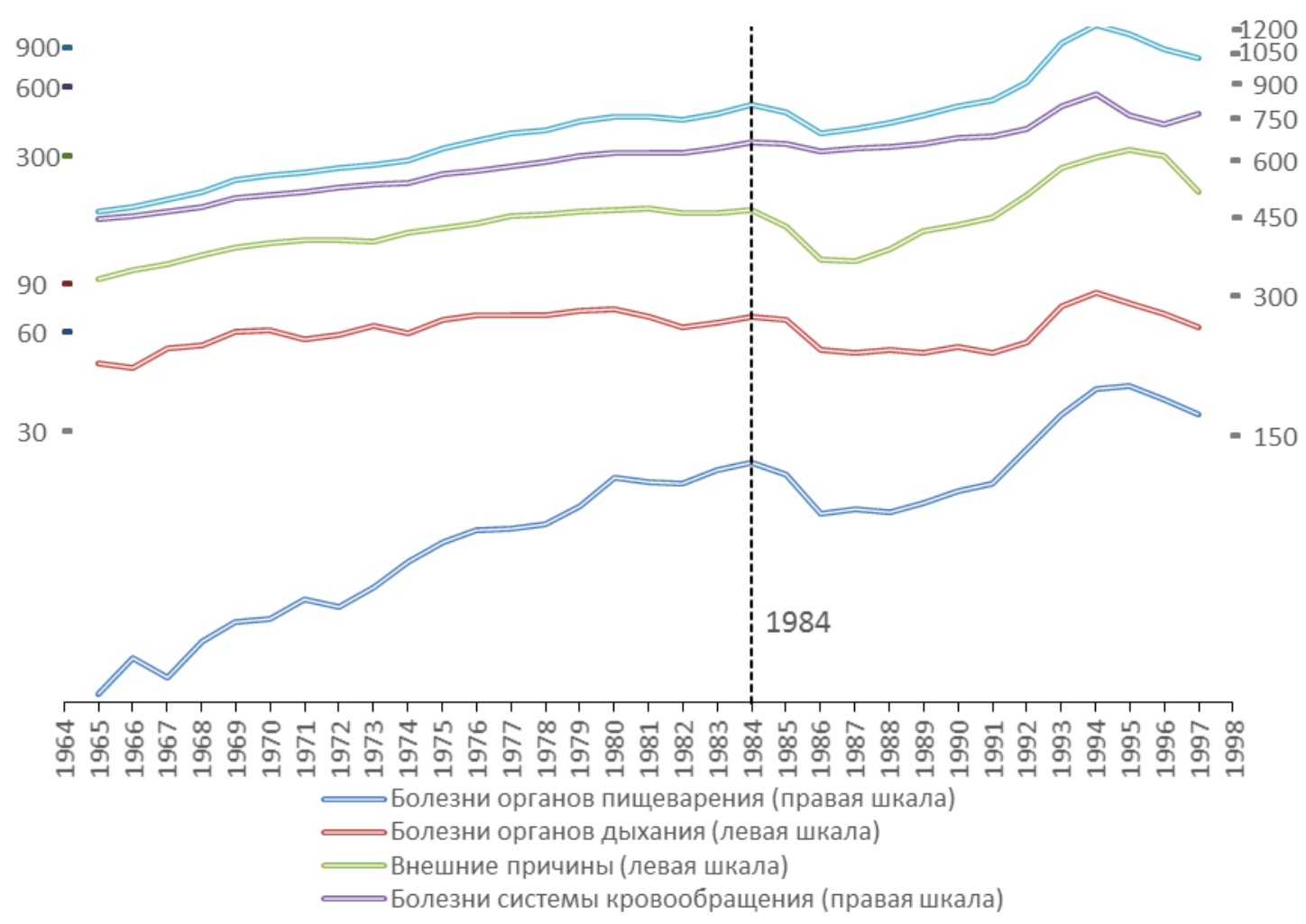

\section{Рисунок 10. Число мужчин, умерших в 1965-1995 гг. от некоторых классов причин смерти, тысяч}

Источник: [Nemtsov 2002].

Трудно согласиться с Pridemore и соавторами [Pridemoreetal. 2014], что действие законов 2005 г. обусловило длительное снижение смертности и задержало восстановительный период: снижению смертности в 2006 г. и позже предшествовало снижение в 2004-2005 гг. Введение законов действительно ускорило снижение, но продолжалось оно 2 года [Немцов, Шелыгин 2014], а позже вернулось к исходным темпам 2004-2005 гг. с последующим и постепенным замедлением. Это особенно отчетливо проявилось в отношении смертей от отравления алкоголем (рисунок 11), число которых после длительного снижения впервые выросло в 2014 г. по сравнению с 2013 г. (на 6,2\% у мужчин и на 1,7\% у женщин).

Тем не менее затянувшееся снижение смертности в 2004-2014 гг. - непреложный факт, и он требует объяснения.

Удивительно, что обсуждение алкогольной политики в связи со снижением смертности обычно начинается с 2006-2007 гг., тогда как РАР, часто обозначаемое как регулятор рынка, было создано в 2000 г., а снижение смертности началось в 2004 г. По сути, 
перечисленные и некоторые другие авторы в своих объяснениях феномена смертности после 2003 г. опираются на детализированные демографические показатели и общие соображения об их связи со снижением потребления алкоголя, хотя эта связь оценивается по-разному. Важно отметить, что потребление алкоголя, а проще говоря, выпивка, является водоразделом между множественными причинами, приводящими к выпивке [Немцов 2009], и последствиями этого занятия. Среди следствий самой тяжкой и наиболее наглядной является смерть в результате злоупотребления. Поэтому основная часть исследований выполнена по одну сторону водораздела - на поле изучения связей между потреблением алкоголя и смертностью. Другая сторона от этого водораздела, поле связей между причинами злоупотребления и выпивкой часто остается непаханым. В результате причинно-следственная цепочка оказывается незамкнутой. Или в роли причин выступают случайные факторы, как это было с законами 2005 г.

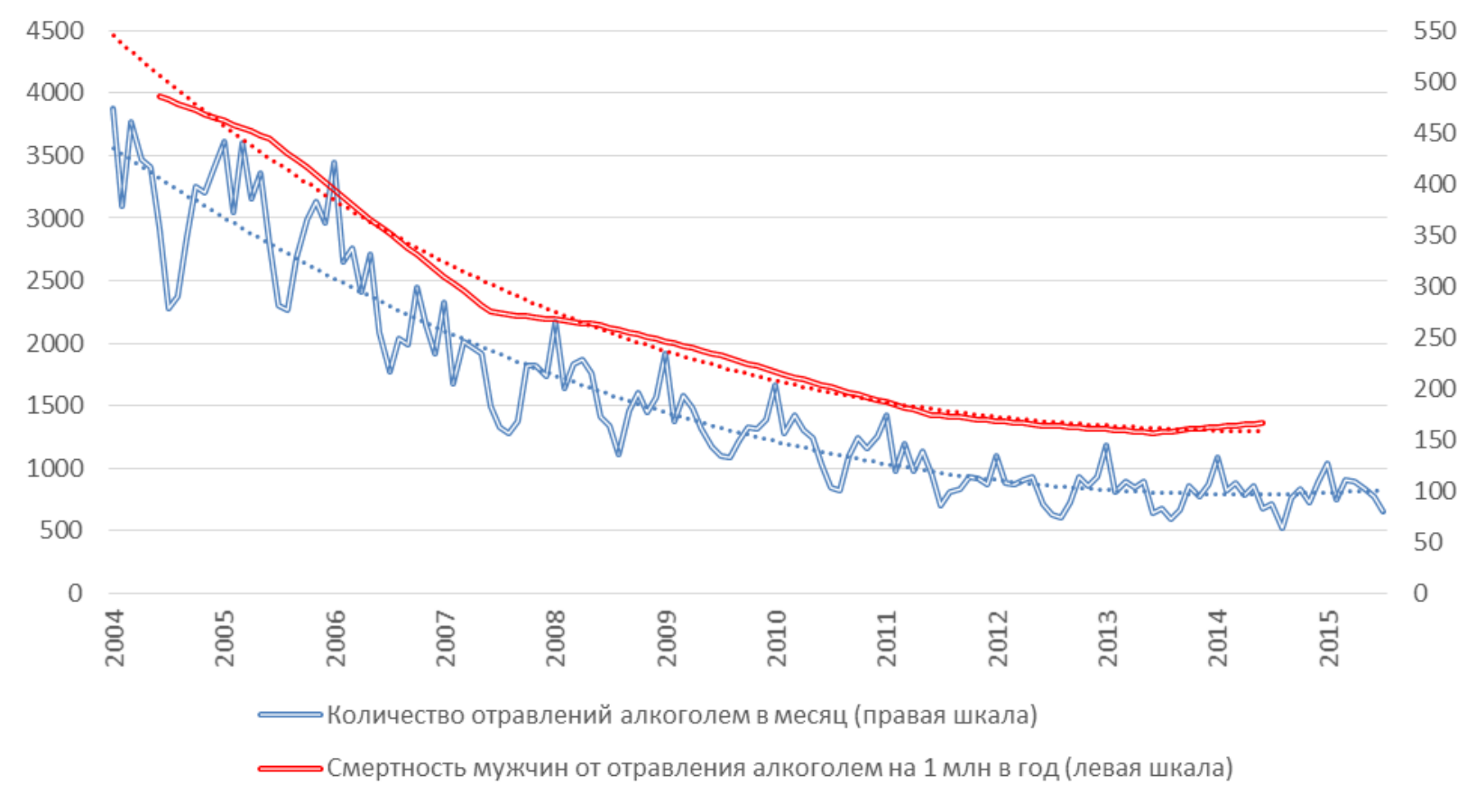

Рисунок 11. Смертность мужчин от отравления алкоголем в 2004-2015 гг.

Примечание: Синяя линия - месячные данные (Росстат); красная - годичные показатели; пунктир полином третьей степени.

Повторюсь в который раз, что снижение смертности началось за 2 года до введения этих законов, а это значит, что были причины смены роста на снижение. Если оставить в стороне трудноуловимые психологические или некоторые другие факторы, подводящие к выпивке и ее следствиям, представляется, что причины снижения смертности, начавшегося в 2004 г., отражены в таблице (см. Приложение): никогда в новейшей истории России [Немцов 2009], включая антиалкогольную кампанию 1985 г., политический напор не был столь продолжительным, хотя и непоследовательным. На этот раз давление оказывалось на алкогольный рынок с целью подавления нелегального производства и пополнения бюджета.

Одной из возможных причин снижения смертности в связи со снижением потребления алкоголя в последние годы иногда называют изменение состава потребляемых 
алкогольных напитков (см. выше). Однако это пока маловероятно в силу того, что доминирование пива у части потребителей началось сравнительно недавно, около 15 лет назад (рисунок 10), и касалось преимущественно молодых людей, которые еще не скоро реализуют свой низкий риск умереть алкогольной смертью в связи с переходом на пиво.

В газетных публикациях и выступлениях чиновников в качестве другой причины называются меры прямого действия: ограничения продажи спиртного по возрасту (18+), месту (школы и т.д.) и времени (ночной запрет). Эффективность этих мер исследовалась только однажды в связи с ночным ограничением [Колосницына и др. 2015]. Авторы сочли, что ограничение времени продаж привело к их снижению. Но это было показано на примере одного года (2010 г. по отношению к 2009 г.) без учета того, что снижение в этот период происходило на фоне снижения, начавшегося в 2004 г. (рисунок 6), а график не обнаруживает изменения тренда продаж в 2010 г. и позже. Так что эффективность этой меры пока нельзя считать доказанной.

\section{ЗАКЛЮЧЕНИЕ}

В 2000 г. началась вторая антиалкогольная кампания, необъявленная, в отличие от первой. Связанные с ней действия не были рациональными и последовательными. Более того, алкогольная политика в России не имеет под собой никакого научного обоснования. Несмотря на существенное снижение потребления алкоголя и смертности, эту кампанию нельзя признать направленной на оздоровление населения.

Объектом первой кампании был потребитель, второй - алкогольный рынок, а в нем в первую очередь - производитель.

Целью первой кампании было снижение потребления, а с помощью этого оздоровление хиреющей экономики наряду с другими столь же наивными экономическими мерами. Главной целью второй кампании было наполнение бюджета, сильно похудевшего на исходе советской власти и в «лихие 1990-е», с помощью подавления нелегального рынка и перевода потребителей вместе с их денежными средствами в лоно рынка легального.

Методы первой кампании: снижение производства и ограничение торговли. Методы второй были более разнообразными, они менялись по ходу кампании. Главным оставалось вытеснение с рынка мелких и средних производителей крепких напитков. Они, как предполагалось, являются основными поставщиками нелегальной продукции. При этом происходило интенсивное перераспределение активов в пользу крупных их держателей, которые, как считалось, смогут монополизировать рынок и навести там порядок. К методам второй кампании следует отнести ЕГАИС, многие другие затруднения для участников алкогольного рынка, рост акцизов и минимальной цены на спиртное. Среди методов была жесткая, порой криминальная конкуренция, которая иногда влияла на законодательные решения, как это было с законодательным ущемлением пивной отрасли, конкурирующей с производителями водки за потребителя. 
Инструментом первой кампании стало административное давление, осуществляемое через местные органы КПСС. Главными инструментами второй стали последовательно РСП и РАР со все расширяющимися фискальными полномочиями.

B pезультате не произошло ни оздоровления экономики в первую кампанию, ни пополнения бюджета за счет алкоголя во вторую. Благотворное снижение потребления алкоголя и смертности в первую кампанию было непродолжительным. Вторая кампания в этом отношении была более эффективной в связи с надвигавшимся, а позже надвинувшимся экономическим кризисом и дефицитом бюджета, а снижение потребления алкоголя и смертности было побочным продуктом поиска бюджетных средств в сфере алкогольного рынка. И та, и другая кампания вызвали рост потребления нелегального алкоголя.

Причина неудачи как первой, так и второй кампании - неквалифицированное руководство, отсутствие научной разработки алкогольной политики, бедность населения, недоучет того, что алкоголь входит в сферу потребностей большой части населения. Вторая кампании отличалась от первой более мощной коррупционной составляющей - нельзя навести порядок в локальном секторе экономики при том, что в стране коррупция стала системообразующим фактором.

Провал первой кампании обозначил возврат госпродажи спиртного в 1988 г. Конец второй кампании, точнее конец ее первого этапа, был отмечен «планом мероприятий ("дорожная карта") по стабилизации ситуации и развитию конкуренции на алкогольном рынке», утвержденным 26 ноября 2015 г. «Карта» обнаружила, что 15-летняя кампания не дала желаемых результатов и нужны новые усилия для достижения целей, поставленных в 2000 г. Но этим дело не ограничилось: 15 января 2016 г. Президент подписал Указ о подчинении РАР Министерству финансов и передаче министерству функций по выработке и реализации алкогольной политики. Тем самым были окончательно обнаружены истинные цели второй антиалкогольной кампании и обозначено начало ее второго этапа.

\section{ЛИТЕРАТУРА}

АЛКОГОЛЬ.РУ. Нереализованная концепция 6-летней работы PAP. URL: http://alkohole.ru/news/alko-news/poryadok-v-otrasli (дата обращения: 24.10.2015).

Бехтель Э.Е. (1986). Донозологические формы злоупотребления алкоголем. М.: «Медицина».

Боярина Е. (2001). "Росспиртпром" лезет в бутылку // Совершенно секретно (09.07.2001).

Колосницына М., Х. Доржиев, Н. Хоркина, М. Ситдиков (2015). Меры антиалкогольной политики - работают ли в России? // ДемоскопWeekly. № 665-666. URL: http://demoscope.ru/weekly/2015/0665/index.php (дата обращения: 24.10.2015).

Космарская Т.(1998). Проблемы государственного регулирования рынка алкогольной продукции // Вопросы экономики. №5: 139-145.

Немцов А.В. (2009). Алкогольная история России. Новейший период. M.: URSS.

Немцов А.В., А. Терехин (2007). Размеры и диагностический состав алкогольной смертности в России // Наркология. №12: 29-36. 
Немцов А.В., К.В. Шелыгин (2014). Потребление алкоголя в России: 1956-2012 гг. // Вопросы наркологии. №5: 3-12.

Немцов А.В., К.В. Шелыгин (2015). Антиалкогольные законы 2005 г. и снижение потребления алкоголя в России // Вопросы наркологии. №1: 83-93.

Нужный В.П., В.В. Рожанец, С.А. Савчук (2011). Химия и токсикология этилового спирта и напитков, изготовленных на его основе: Токсикология. М.: ЛИБРОКОМ.

Основные показатели деятельности наркологической службы в Российской Федерации в 2010-2011 годах (2012). Статистический сборник. М.

Соколов И.А. (2013). Исследование акцизной нагрузки на отдельные категории алкогольных продуктов (вино, пиво, крепкий алкоголь) в разных странах мира. Институт экономической политики им. Е.T. Гайдара. Препринт.URL: http://www.iep.ru/ru/issledovanie-akciznoi-nagruzki-na-otdelnye-kategorii-alkogolnyproduktov-vino-pivo-krepkii-alkogol-v-razny-strana-mira.html (дата обращения: 24.10.2015).

Такала И.Р. (2002). Веселие Руси. История алкогольной проблемы в России. СПб.: Журнал "Нева".

Школьников В., Е. Андреев, М. Макки, Д. Леон (2014). Рост продолжительности жизни в России 2000-х годов // Демографическое обозрение. Т.1. №2: 5-37.

Andrienko Y., A. Nemtsov (2006). Estimation of individual demand for alcohol. Economics Education and Research Consortium. Working Paper Series. №05/10. URL: http://www.cefir.ru/index.php?l=eng\&id=35\&yf=2006 (data accessed: 24.10 .2015 ).

Denisova I., M. Kartseva (2012). Alcoholism and the Russian mortality crisis // Public Health Methology, Environmental and Systems Issues / J. Maddock, ed.: 367-386.

Grigoriev P, E.M. Andreev (2015). The huge reduction in adult male mortality in Belarus and Russia: Is it attributable to anti-alcohol measures? // PLoSONE. 10(9). URL: http://dx.doi.org/10.1371/journal.pone.0138021 (data accessed: 24.10.2015).

Holder H.D., G. Edwards (eds.) (1995). Alcohol and public policy: Evidence and issues. OxfordNew York-Toronto-Tokyo: Oxford University Press.

Khalturina D, A. Korotaev (2015). Effects of specific alcohol control policy measures on alcohol-related mortality in Russia from 1998 to 2013 // Alcohol and Alcoholism: 1-14.

Kueng L., E. Yakovlev (2014). How persistent are consumption habits? Micro-evidence from Russia // NBER Working Paper. №20298. URL: http://www.nber.org/papers/w20298 (data accessed: 24.10.2015).

Leon D. et al. (2007). Hazardous alcohol drinking and premature mortality in Russia: a population based case-control study // Lancet. 369: 2001-2009.

Nemtsov A. (1998). Alcohol-related harm and alcohol consumption in Moscow before, during and after a major anti-alcohol campaign // Addiction. 93. №10: 1501-1510.

Nemtsov A. (1999). Alcohol consumption, alcohol-related consequences and alcohol policy in Russia (1945-1996) // Alcologia. 11: 57-61.

Nemtsov A. (2002). Alcohol-related harm losses in Russia in the 1980s and 1990s // Addiction. 97: 1413-1425. 
Neufeld M., J. Rehm (2013). Alcohol consumption and mortality in Russia since 2000: are there any changes following the alcohol policy changes starting in 2006? // Alcohol and Alcoholism. 48(2): 222-230.

OECD (2015). Tackling harmful alcohol use. Economics and public health policy / Franco Sassi, ed. OEDS Publishing.

Pridemore W.A., M.B. Chamlin, M.T. Kaylen, E. Andreev (2014). The effects of the 2006 Russian alcohol policy on alcohol-related mortality: An interrupted time series analysis // Alcoholism: Clinical and Experimental Research. 38(1): 257-266.

Radaev V. (2015). Impact of a new alcohol policy on homemade alcohol consumption and sales in Russia // Alcohol and Alcoholism. 25: 1-8.

Razvodovsky Y.E. (2012). Estimation of alcohol attributable fraction of mortality in Russia // Adicciones. 24(3): 247-52.

Room R. (1991). Cultural changes in drinking and trends in alcohol problems indicators: recent US experience // W.G. Clark and M.E. Hikton, eds. Alcohol in America. Albany N.Y. SUNT Press: 149-162.

Shkolnikov V., A. Nemtsov (1997). The anti-alcohol campaign and variations in Russian mortality // J.L. Bobadilla, C.A. Costello, F. Mitchell, eds. Premature Death in the New Independent State. Washington DC: National Academy Press.

Shkolnikov V.M, E.M. Andreev, D.A. Leon, M. McKee, F. Meslé, J. Vallin (2004). Mortality reversal in Russia: the story so far // Hygiea Internationalis. 4(4): 29-80.

Simpura J. (1995). Alcohol use and associated risk of harm // H.D Holder, G. Edwards, eds. Alcohol and Public Policy: Evdence and Issues. Oxford University Press: 7-37.

Spring J.A., D.H. Buss (1977). Three centuries of alcohol in Britain // Nature. 270: 567-572.

Treml V. (1982). Alcohol in the USSR. Statistical study. Durham, N.C.: Duke Press Policy Studies.

WHO (2014). Global status report on alcohol and health.

Zaridze D. (2014). Alcohol and mortality in Russia: prospective observational study of 151000 adults// Lancet. 9927. №383: 1465-1473. 


\title{
MORTALITY IN RUSSIA IN LIGHT OF THE IN ALCOHOL CONSUMPTION
}

\author{
ALEXANDER NEMTSOV
}

Alexander Nemtsov. Moscow Research Institute of Psychiatry (Russia). E-mail: nemtsov33@gmail.com.

DATE RECEIVED: September 2015.

In the contemporary history of Russia, there have been three significant reductions in alcohol consumption associated with a decrease in mortality. The first, resulting from the anti-alcohol campaign of 1985, lasted 3 years, and the second, resulting from the impoverishment of the population and death of a large part of heavy drinkers, 4 years (1995-1998).

In 2004 began the third decrease in consumption, often inexplicably linked with the anti-alcohol laws of 2005. However, the history of this decline goes back to the year 2000. It started with the creation of Rosspirtprom (RSP) and the anti-beer campaign, with Rosalkogolregulirovanie (RAR) taking over in 2009. The main activities of RSP and RAR involved the bankruptcy of several hundred enterprises of the alcohol industry. This and many other actions of the RSP and the RAR resulted in the instability, sometimes disruption, of the alcohol market. This could be a significant cause of the decrease in consumption and mortality in 2004. In fact, in 2000 the second anti-alcohol campaign started. The object of the first one had been the consumer, of the second, the alcohol market. The aim of the first campaign was to decrease consumption and improve the economy. The aim of the second was to fill the budget by suppressing the illegal market and moving consumers into the legal market. The methods of the first campaign were a reduction of production and trade restrictions; the methods of the second one changed in the course of the campaign. The main goal was to squeeze small and medium-sized players out of the market, on the assumption that they were the principal suppliers of illegal products. The methods of the second campaign included the introduction of a Unified State Automated System, the growth of excise taxes and a minimum price for alcohol, as well as tough, sometimes criminal competition. The tool of the first campaign was administrative pressure. The main instruments of the second one were RSP and then RAR.

As a result, there was neither an economic recovery in the first campaign, nor a filling of the budget thanks to alcohol in the second. The decrease in consumption and mortality in the first campaign was short-lived. The second campaign was in this regard more effective, due to the economic crisis and the growing budget deficit. Both campaigns led to increased consumption of illegal alcohol.

Key words: alcohol consumption, mortality in Russia, anti-alcohol campaign, illegal alcohol.

\section{REFERENCES}

ALKOGOL'.RU. Nerealizovannaya kontseptsiya 6-letney raboty RAR [Unrealized concept of the six year work of PAP]. URL: http://alkohole.ru/news/alko-news/poryadok-v-otrasli (data accessed: 24.10.2015).

Andrienko Y., A. Nemtsov (2006). Estimation of individual demand for alcohol. Economics Education and Research Consortium. Working Paper Series. №05/10. URL: http://www.cefir.ru/index.php?l=eng\&id=35\&yf=2006 (data accessed: 24.10 .2015 ).

Bekhtel' E.Ye. (1986). Donozologicheskiye formy zloupotrebleniya alkogolem [Prenosological forms of alcohol abuse]. M.: Meditsina [Medicine].

Boyarina Ye. (2001). "Rosspirtprom" lezet v butylku ["Rosspirtprom" goes into the bottle] // Sovershenno sekretno [Top Secret]. (09.07.2001).

Denisova I., M. Kartseva (2012). Alcoholism and the Russian mortality crisis // Public Health Methology, Environmental and Systems Issues / J. Maddock, ed.: 367-386. 
Grigoriev P, E.M. Andreev (2015). The huge reduction in adult male mortality in Belarus and Russia: Is it attributable to anti-alcohol measures? // PLoSONE. 10(9). URL: http://dx.doi.org/10.1371/journal.pone.0138021 (data accessed: 24.10.2015).

Holder H.D., G. Edwards (eds.) (1995). Alcohol and public policy: Evidence and issues. OxfordNew York-Toronto-Tokyo: Oxford University Press.

Khalturina D, A. Korotaev (2015). Effects of specific alcohol control policy measures on alcohol-related mortality in Russia from 1998 to 2013 // Alcohol and Alcoholism: 1-14.

Kolosnitsyna M., KH. Dorzhiyev, N. Khorkina, M. Sitdikov (2015). Mery antialkogol'noy politiki - rabotayut li v Rossii? [Measures of anti-alcohol policy - do the work in Russia?] // Demoscope Weekly. № 665-666. URL: http://demoscope.ru/weekly/2015/0665/index.php (data accessed: 24.10.2015)

Kosmarskaya T. (1998). Problemy gosudarstvennogo regulirovaniya rynka alkogol'noy produktsii [Problems of state regulation of the alcohol market] // Voprosy ekonomiki [Economic Questions]. №5: 139-145.

Kueng L., E. Yakovlev (2014). How persistent are consumption habits? Micro-evidence from Russia // NBER Working Paper. №20298. URL: http://www.nber.org/papers/w20298 (data accessed: 24.10.2015).

Leon D. et al. (2007). Hazardous alcohol drinking and premature mortality in Russia: a population based case-control study // Lancet. 369: 2001-2009.

Nemtsov A. (1998). Alcohol-related harm and alcohol consumption in Moscow before, during and after a major anti-alcohol campaign // Addiction. 93. №10: 1501-1510.

Nemtsov A. (1999). Alcohol consumption, alcohol-related consequences and alcohol policy in Russia (1945-1996) // Alcologia. 11: 57-61.

Nemtsov A. (2002). Alcohol-related harm losses in Russia in the 1980s and 1990s // Addiction. 97: 1413-1425.

Nemtsov A.V. (2009). Alkogol'naya istoriya Rossii. Noveyshiy period [Alcohol history of Russia. The latest period]. M.: URSS.

Nemtsov A.V., A. Terekhin (2007). Razmery i diagnosticheskiy sostav alkogol'noy smertnosti v Rossii [The size and diagnostic structure of the alcohol mortality in Russia] // Narkologiya [Narcology]. №12: 29-36.

Nemtsov A.V., K.V. Shelygin (2014). Potrebleniye alkogolya v Rossii: 1956-2012 gg. [Alcohol consumption in Russia: 1956-2012] // Voprosy narkologii [Questions of Narcology]. №5: 312.

Nemtsov A.V., K.V. Shelygin (2015). Antialkogol'nyye zakony 2005 g. i snizheniye potrebleniya alkogolya $\mathrm{v}$ Rossii [Anti-alcohol laws in 2005 and the reduction of alcohol consumption in Russia] // Voprosy narkologii [Questions of Narcology]. №1: 83-93.

Neufeld M., J. Rehm (2013). Alcohol consumption and mortality in Russia since 2000: are there any changes following the alcohol policy changes starting in 2006? // Alcohol and Alcoholism. 48(2): 222-230.

Nuzhnyy V.P., V.V. Rozhanets, S.A. Savchuk (2011). Khimiya i toksikologiya etilovogo spirta i napitkov, izgotovlennykh na yego osnove: Toksikologiya [Chemistry and Toxicology of the ethyl alcohol and beverages produced on its basis: Toxicology]. M.: LIBROKOM.

OECD (2015). Tackling harmful alcohol use. Economics and public health policy / Franco Sassi, ed. OEDS Publishing. 
Osnovnyye pokazateli deyatel'nosti narkologicheskoy sluzhby v Rossiyskoy Federatsii v 20102011 godakh [Main indicators of the drug abuse service performance in the Russian Federation in 2010-2011] (2012). Statisticheskiy sbornik [Statistical Book]. Moscow.

Pridemore W.A., M.B. Chamlin, M.T. Kaylen, E. Andreev (2014). The effects of the 2006 Russian alcohol policy on alcohol-related mortality: An interrupted time series analysis // Alcoholism: Clinical and Experimental Research. 38(1): 257-266.

Radaev V. (2015). Impact of a new alcohol policy on homemade alcohol consumption and sales in Russia // Alcohol and Alcoholism. 25: 1-8.

Razvodovsky Y.E. (2012). Estimation of alcohol attributable fraction of mortality in Russia // Adicciones. 24(3): 247-52.

Room R. (1991). Cultural changes in drinking and trends in alcohol problems indicators: recent US experience // W.G. Clark and M.E. Hikton, eds. Alcohol in America. Albany N.Y. SUNT Press: $149-162$.

Shkolnikov V., A. Nemtsov (1997). The anti-alcohol campaign and variations in Russian mortality // J.L. Bobadilla, C.A. Costello, F. Mitchell, eds. Premature Death in the New Independent State. Washington DC: National Academy Press.

Shkol'nikov V., Ye. Andreyev, M. Makki, D. Leon (2014). Rost prodolzhitel'nosti zhizni v Rossii 2000-kh godov [The increase in life expectancy in Russia of the 2000s] // Demograficheskoye obozreniye [Demographic Review]. V.1. №2: 5-37.

Shkolnikov V.M, E.M. Andreev, D.A. Leon, M. McKee, F. Meslé, J. Vallin (2004). Mortality reversal in Russia: the story so far //Hygiea Internationalis. 4(4): 29-80.

Simpura J. (1995). Alcohol use and associated risk of harm // H.D Holder and G. Edwards (eds.) Alcohol and Public Policy: Evdence and Issues. Oxford University Press: 7-37.

Sokolov I.A. (2013). Issledovaniye aktsiznoy nagruzki na otdel'nyye kategorii alkogol'nykh produktov (vino, pivo, krepkiy alkogol') v raznykh stranakh mira [Research of excise burden on certain categories of alcoholic products (wine, beer, spirits) around the world]. Institut ekonomicheskoy politiki im. Ye.T. Gaydara [Gaydar Institute of Economic Policy]. Preprint.URL: http://www.iep.ru/ru/issledovanie-akciznoi-nagruzki-na-otdelnye-kategoriialkogolny-produktov-vino-pivo-krepkii-alkogol-v-razny-strana-mira.html (data accessed: 24.10.2015).

Spring J.A., D.H. Buss (1977). Three centuries of alcohol in Britain // Nature. 270: 567-572.

Takala I.R. (2002). Veseliye Rusi. Istoriya alkogol'noy problemy v Rossii [Merrymaking in Russia. History of alcohol problems in Russia]. St. Petersburg: Zhurnal "Neva" [Journal "Neva"].

Treml V. (1982). Alcohol in the USSR. Statistical study. Durham, N.C.: Duke Press Policy Studies.

WHO (2014). Global status report on alcohol and health.

Zaridze D. (2014). Alcohol and mortality in Russia: prospective observational study of 151000 adults // Lancet. 9927. №383: 1465-1473. 


\section{ПРИЛОЖЕНИЕ}

\section{Хронология государственных мероприятий в сфере алкогольной политики}

\begin{tabular}{l|l}
\hline Год & \multicolumn{1}{c}{ Мероприятия } \\
\hline 2000 & Постановление Правительства о создании ФГУП Росспиртпрома (6 мая) с подчинением ему \\
& более 200 спиртовых и ликероводочных заводов. \\
& Договор с Минсельхозом РФ о передаче ФГУП Росспиртпрому права распределять
\end{tabular}
ежегодные квоты на спирт

Постановление Первого заместителя Министра здравоохранения и Главного государственного санитарного врача РФ Г.Г.Онищенко "Об усилении Госсанэпиднадзора за пивоваренной продукцией".

2001 Арбитражный суд Москвы признал недействительным соглашение Минсельхоза РФ и Росспиртпрома о квотах на спирт.

2002 Смена руководства ФГУП Росспиртпрома.

2003 Перевод клиентских счетов заводов, принадлежащих Росспиртпрому в два банка: «Северный морской путь» и «Международный банк торгового сотрудничества» (братья А. и Б. Ротенберги).

2004 Новая редакция закона 186-Ф3: увеличение налога на этиловый спирт из пищевого сырья на $50 \%$ (вступил в силу с 01.01.2005).

Введение новых акцизных марок для алкогольной продукции.

2005 Закон «Об ограничениях розничной продажи и потребления (распития) пива и напитков, изготавливаемых на его основе» (март - № 11-ФЗ)

Закон 102-Ф3 помимо прочего вводил новые федеральные (акцизные) марки на алкогольную продукцию с 1 января 2006. С этого же времени запрещалось использовать прежние марки (июль)

Закон 209-ФЗ существенно увеличивал уставной капитал акторов алкогольного рынка с 1 июля 2006. Этот закон кроме того вводил новые и более токсичные денатурирующие добавки с 1 июля 2006 (бензин, керосин, кротональдегид и другие) - декабрь

2006 Начало действия законов 2005 г. (102-Ф3 с 1 января и 209-Ф3 с 1 июля).

Первая попытка внедрения Единой государственной автоматизированной информационной системы (ЕГАИС) с 1 января 2006 г.

Региональные власти получили право вводить ограничения времени розничной продажи алкоголя для алкогольных напитков с содержанием этанола $>15 \%$ и определять уставный капитал для розничных продавцов.

2007 Запрет продажи парфюмерии без ее денатурации.

2008-2009 Создание Росалкогольрегулирования с правом разработки государственной политики в сфере производства и оборота этилового спирта и алкогольной продукции, а также правом контролем за реализацией алкогольной политики.

2009 Концепция гос. политики по сокращению связанного с алкоголем вреда и профилактике алкоголизма на период 2010-2020 гг.

Комиссия по регулированию алкогольного рынка (руководитель Первый заместитель председателя правительства В.Зубков)

2010 Первое введение минимальных цен на водку (89 руб. за полулитровую бутылку) и другую алкогольную продукцию.

2011 Требование к спиртовым заводам закупки специальной и дорогостоящего оборудования для переработки отбросов производства в корма для скота. Предприятия, не выполнившие это требование, лишались возобновления своих лицензий.

Повышение минимальной цены на водку (98 руб. за полулитровую бутылку).

Новая редакция закона 171-ФЗ Это относится к 2011 г.

2012 Повышение налога на спирт в реальном выражении на 22\%.

Всероссийский запрет на продажу всех видов алкогольных напитков с 23 до 8 часов утра следующего дня. Запрет на розничную продажу алкогольной продукции в детских, образовательных, медицинских организациях, на объектах спорта и прилегающих к ним территориях.

Увеличение уставного капитала для производителей алкогольной продукции на 40\%;

Расширение перечня мест, где запрещалась продажа алкогольных напитков. Незначительное увеличение штрафов за эти нарушения.

Продление запрета продажи алкогольных напитков в киосках и расширение запрета на все виды напитков (с 1995 г. - только на крепкие напитки).

Регионам предоставлялось право самим устанавливать ограничения для мест и условий 


\begin{tabular}{|c|c|}
\hline Год & Мероприятия \\
\hline & розничной продажи алкогольных напитков. \\
\hline & Лицензирование перевозки этилового спирта. \\
\hline & Запрет рекламы пива и вина (из отечественного винограда) на телевидении. \\
\hline & Повышение минимальной цены на водку (125 руб.) \\
\hline \multirow[t]{3}{*}{2013} & Запрет продажи пива в нестационарных торговых объектах. \\
\hline & Увеличение налога на алкогольные напитки на 27\%. \\
\hline & Повышение минимальной цены на водку (170 руб.). \\
\hline \multirow[t]{2}{*}{2014} & Повышение минимальной цены на водку (220 руб.). \\
\hline & Комиссия по регулированию алкогольного рынка (руководитель вице-премьер \\
\hline 2015 & Разрешение рекламы пива и вина (из отечественного винограда) на телевидении. \\
\hline & Очередное и окончательное распоряжение РАР о внедрении ЕГАИС с 01.01.2016. \\
\hline & РАР предложила концепцию антиалкогольной кампании стоимостью в 2,3 млрд. рублей \\
\hline & Снижение минимальной цены на водку до 185 руб. \\
\hline & $\begin{array}{l}\text { План мероприятий ("дорожная карта") по стабилизации ситуации и развитию конкуренции } \\
\text { на алкогольном рынке, утвержденный 26.11.2015 г. }\end{array}$ \\
\hline 2016 & $\begin{array}{l}\text { Подчинение РАР Минфину с передачей министерству функций по выработке и реализации } \\
\text { алкогольной политики. }\end{array}$ \\
\hline
\end{tabular}

